\title{
The Revised Dalhousie Clerkship Changes and Future Directions
}

It has been six years since the Dalhousie medical curriculum was significantly overhauled with the introduction of Case-Oriented Problem Based (COPS) learning into the first two years of medical training. This change was designed to prepare students to deal with ever increasing volumes of medical information and to facilitate learning around patient cases instead of through pure didactic teaching methodologies. Now, the clerkship has fallen under scrutiny and major changes are in the works. On November 19 19 th 1998 , a formal draft document entitled "Proposal for Revised Clerkship" was released by the Clerkship Review Committee headed by the Associate Dean of Undergraduate Medical Education and Student Affairs, Dr. Micheline Ste-Marie. The document was released after several months of committee discussions and town hall meetings. The new clerkship system is to be implemented in August of 1999 for the new incoming clerks.

Several town hall meetings were arranged to facilitate open discussion on various aspects of the new clerkship. There was also a video conference link with sites in New Brunswick to facilitate input from faculty outside of Nova Scotia. At the town hall meeting on November $9^{\text {th }}$ the question was raised as to why the system had to be changed in the first place. It was clearly stated at this meeting that it would be "mathematically impossibile" to continue to administrate the clerkship as it was currently organized. Therefore, it was indicated that change was not an option, but rather a necessity. In addition, a review of the current clerkship had identified a number of areas in the current clerkship that required improvement.

Following this town hall meeting the "Proposal for Revised Clerkship" was released as a draft document to stimulate discussion. One of the major problems identified with the current clerkship was that it did not have a sufficient "integration of objectives and learning experiences" between clerkship rotations. There had been some discussion at the town hall meeting of having integrated rotations in the new clerkship that were not departmentally based. However, the recently released clerkship proposal still appears to be predominantly based on departmentally structured rotations. The report stated that, "a departmental structure for organizing a clerkship seems to make sense since the entire faculty is organized departmentally." However, the emphasis in the new clerkship will be to have more integration between disciplines in each rotation, clear objectives and skills that are to be learned and a formal system of evaluation to assess students' skills and knowledge.

The basic design of the proposal for the new clerkship involves an introductory month followed by two distinct phases (Tables 1-3). Phase I is organized according to traditional clinical departments and will involve four groups of students being assigned to twelve week units entitled: Medical, Primary Care, Surgical and Women \& Children's Health. There is to be a formal evaluation at the end of each twelve week unit. Each twelve week unit will be further subdivided into three rotations of four weeks. Phase II begins with electives, followed by time for CaRMS interviews and finally a block entitled Continuing and Preventative Care.

The new clerkship system appears to have a number of advantages over the previous model, such as a one month introduction to clerkship where skills can be taught formally to students and form a framework of skills for core rotations. Another possible benefit is the placement of the electives after all the core placements have been done, the rationale being that students will have acquired basic clinical skills and will be able to function effectively on their electives. However, the electives period falls between September $11^{\text {th }}$ and December $3^{\text {rd }}$ which would be when deadlines for the Canadian Residency Matching Service (CaRMS) are set. For example, according to the 1998 CaRMS schedule the "Application Designation List", which specifies which programs an applicant wishes to apply to, was to be at CaRMS by September $30^{\text {th }}$. Given the fact that electives are often used as times to explore possible career options, they should logically precede when decisions are made about the career path that one chooses. As the electives are currently placed students would be selecting programs while they are in the middle of their elective block. This problem would be partially offset by the the increased flexibility of rotations in the proposed phase I. As the current proposal stands, 24 of the 48 weeks in phase I would involve some choice on the part of the student. Although this would allow students to use their core experiences to explore different career options it would still be optimal to have the possibility of elective experiences earlier in the clerkship.

The last town hall meeting was held on December $14^{\text {th }}$ and it appears that there are many other questions that will have to be resolved as the new clerkship is designed and evolves over the following months. How will departmental rotations such as ENT/Ophthalmology and Urology be scheduled or integrated into the new system? What will be considered mandatory rotations? What type of new evaluations will be used? How will departmentally based rotations implement broader objectives? How will consistency be generated between departments with respect to quality of education and evaluations? How will the service component of clerkship be integrated into the new design?

The proposal for a new clerkship has been accompanied by mixed feelings of anxiety and excitement at all levels of the medical hierarchy. Any time there is a major change to the system there is likely to be growing pains. The question 
is whether the growing pains will ultimately lead to a significantly better medical education system. There are many groups and departments with stakes in the new clerkship. However, it is the first and second year medical students entering the new program who have the most at stake in the implementation of this new system.

I think that open discussion on this topic will continue to shape both the design and implementation of the new clerkship. As such, I will be reinstituting the "Letters to the Editor" section in the next edition of the $D M J$ and I invite the opinions of the $D M J$ readership on this topic and hope to pub- lish a selection of the letters in the next edition. I hope that the process of clerkship review continues to be an open process that will involve all members of the Dalhousie Medical Community and will strive to balance diverse ideas to ultimately create a clerkship design that will be the envy of the other Canadian medical schools.

Brent Williams

Editor-in-Chief

December 1998

Table 1: Phase I of Proposed Clerkship Schedule

\begin{tabular}{|c|c|c|c|c|c|c|c|c|c|c|c|c|c|c|}
\hline & I & A & & & $\mathrm{V}$ & B & & & C & & & D & & \\
\hline Block \# & & 1 & 2 & 3 & & 4 & 5 & 6 & 7 & 8 & 9 & 10 & 11 & 12 \\
\hline Weeks & 4 & 4 & 4 & 4 & 2 & 4 & 4 & 4 & 4 & 4 & 4 & 4 & 4 & 4 \\
\hline $\begin{array}{l}\text { Start } \\
\text { Date } \\
\end{array}$ & \begin{tabular}{|l} 
Aug \\
$30 / 99$ \\
\end{tabular} & $\begin{array}{l}\text { Sept } \\
27 / 99 \\
\end{array}$ & $\begin{array}{l}\text { Oct } \\
25 / 99 \\
\end{array}$ & $\begin{array}{l}\text { Nov } \\
22 / 99 \\
\end{array}$ & \begin{tabular}{|l} 
Dec \\
$20 / 99$ \\
\end{tabular} & \begin{tabular}{|l} 
Jan \\
$3 / 00$ \\
\end{tabular} & $\begin{array}{l}\text { Jan } \\
31 / 00 \\
\end{array}$ & $\begin{array}{l}\text { Feb } \\
28100 \\
\end{array}$ & $\begin{array}{l}\text { Mar } \\
27 / 00 \\
\end{array}$ & $\begin{array}{l}\text { Apr } \\
24 / 00 \\
\end{array}$ & $\begin{array}{l}\text { May } \\
22200 \\
\end{array}$ & $\begin{array}{l}\text { June } \\
19 / 00 \\
\end{array}$ & $\begin{array}{l}\text { July } \\
17 / 00 \\
\end{array}$ & $\begin{array}{l}\text { Aug } \\
14 / 00 \\
\end{array}$ \\
\hline $\begin{array}{l}\text { Finish } \\
\text { Date }\end{array}$ & $\begin{array}{l}\text { Sept } \\
24 / 99 \\
\end{array}$ & $\begin{array}{l}\text { Oct } \\
24 / 99\end{array}$ & $\begin{array}{l}\text { Nov } \\
21 / 99\end{array}$ & $\begin{array}{l}\text { Dec } \\
19 / 99\end{array}$ & $\begin{array}{l}\text { Jan } \\
2 / 00\end{array}$ & $\begin{array}{l}\text { Jan } \\
30 / 00\end{array}$ & $\begin{array}{l}\text { Feb } \\
27 / 00\end{array}$ & $\begin{array}{l}\text { Mar } \\
26 / 00\end{array}$ & $\begin{array}{l}\text { Apr } \\
23 / 00 \\
\end{array}$ & $\begin{array}{l}\text { May } \\
21 / 00\end{array}$ & $\begin{array}{l}\text { June } \\
18 / 00\end{array}$ & $\begin{array}{l}\text { July } \\
16 / 00\end{array}$ & $\begin{array}{l}\text { Aug } \\
13 / 00\end{array}$ & $\begin{array}{l}\text { Sept } \\
10 / 00\end{array}$ \\
\hline
\end{tabular}

Table 2: Phase II of Proposed Clerkship Schedule

\begin{tabular}{|l|l|l|l|llll|l|}
\hline & Electives & FV & V/I & \multicolumn{2}{|l|}{ Continuing and Preventative Care } & Eval \\
\hline Block \# & 13 & & & 14 & 15 & 16 & 17 & \\
\hline Weeks & 12 & 2 & 4 & 3 & 3 & 3 & 3 & 3 \\
\hline $\begin{array}{l}\text { Start } \\
\text { Date }\end{array}$ & Sept & - & - & Jan & Fcb & Feb & Mar & Apr \\
\hline Finish & $11 / 00$ & - & - & $15 / 01$ & $5 / 01$ & $26 / 01$ & $19 / 01$ & $9 / 01$ \\
Date & - & - & Jan & Feb & Feb & Mar & Apr & Apr \\
& & - & $14 / 01$ & $4 / 01$ & $25 / 01$ & $18 / 01$ & $8 / 01$ & $27 / 01$ \\
\hline
\end{tabular}

Table 3: Overview of Proposed Clerkship Rotations

\begin{tabular}{|c|c|c|c|}
\hline \multirow[t]{2}{*}{ Rotation } & \multicolumn{3}{|c|}{ Time (Weeks) } \\
\hline & Required & Choice & Total \\
\hline \multicolumn{4}{|l|}{ Phase 1 } \\
\hline Introduction to clerkship & 4 & - & 4 \\
\hline Medical & 4 & 8 & 12 \\
\hline Primary Care & 8 & 4 & 12 \\
\hline Surgical & 4 & 8 & 12 \\
\hline Women and Children's Health & 8 & 4 & 12 \\
\hline Christmas Vacation & 2 & - & 2 \\
\hline \multicolumn{4}{|l|}{ Phase 2} \\
\hline Electives & - & 12 & 12 \\
\hline Vacation & - & 2 & 2 \\
\hline Vacation/CaRMS & 4 & $=$ & 4 \\
\hline Continuing and preventive care & 6 & 6 & 12 \\
\hline Evaluation & 3 & - & 3 \\
\hline & 43 & 44 & 87 \\
\hline
\end{tabular}

Abbreviations: $\mathbf{I}=$ Introduction to clerkship A,B,C,D= rotating Medical, Surgical, Primary Care and Women's and Children's Health $\mathbf{V}=$ vacation $\mathbf{V} / \mathbf{I}=$ vacation/interviews $\mathbf{F V}=$ Floating Vacation 


\section{The Dalhousie Medical Journal Needs Your Support}

The Dalhousie Medical Journal is a peer-reviewed journal published by students in the Faculty of Medicine at Dalhousie University. It is the only one of its kind in Atlantic Canada. Although the Journal is financially self-sufficient based on advertising, support from our patrons allows for the development and expansion of the $D M J$. The funds donated thus far by our patrons have been used to purchase supplies and services required for the running of the Journal. Recently the DMJ Editorial Board purchased a Macintosh G3 computer to produce the Journal.

The $D M J$ Editorial Board is now operating in the new Dalhousie Medicine Publications Office following space reallocation in the Tupper Link. The office is also used by the DMSS Handbook committee and the yearbook staff. With this recent move into a proper office it has become necessary to equip the room so that it can serve as a fully functional publication office. Plans are in the works to purchase a scanner, fax machine, printer and photocopier. Continued support from patrons will allow for the expansion of the new Publication Office and facilitate the $D M J$ developing into a forum for research relevant to the health of Atlantic Canadians and as an international forum for the highest quality medical and graduate student research.

To become a Patron of the $D M J$ please send a cheque for $\$ 50.00$ to the address on the adjacent form. You will be acknowledged on both the December 1999 and May 2000 edition of the $D M J$ as a "Patron of the $D M J$ '. Thank-you for your support.
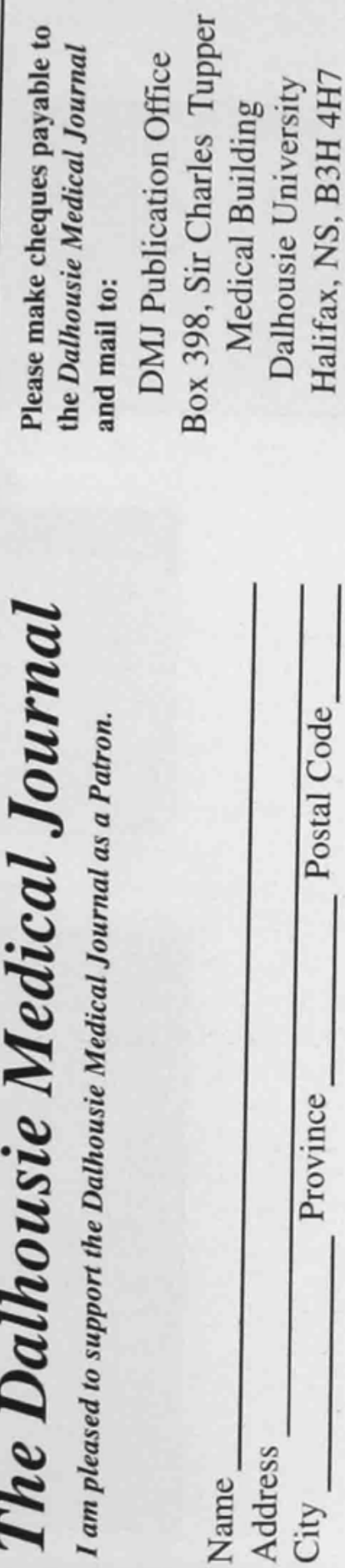


\section{The Medical Society's 1999 Annual Conference}

Mark your calendars today! Digby Pines Resort
May 27-29, 1999

Watch for more details \& registration information in the New Year!

Some of the highlights include:

- President's Welcome Reception

- Continuing Medical Education Session

- General Council Business

- Fun Night

- Keynote Speakers

- Sponsor and Exbibitor Reception

- Awards Ceremony

- President's Dinner and Dance 